\title{
Pakkeforløp ved psykiske sykdommer?
}

«Jeg ser du er forsinket, så jeg skal være rask. Jeg kommer bare for å få en henvisning til psykolog. Jeg trenger noen å snakke med!» Fastleger i de større byene vil gjenkjenne denne bestillingen - som ikke er enkel. For det står ingen psykolog klar og venter. Kompetente fastleger kan selv avklare og hjelpe mange pasienter med psykiske plager. Men av og til trenger de å henvise videre. Mange distriktspsykiatriske sentre tilbyr bare en kort diagnostisk vurdering. Alternativet er at fastlegen må lete seg frem til en avtalespesialist som kanskje har tid og anledning.

Pakkeforløp for kreft er et eksempel på at politiske beslutninger kan forbedre arbeidsmåten i helsevesenet, til fordel for pasientene. For allmennleger gir retningslinjene faglig støtte til å identifisere pasienter med mistanke om kreft og helsepolitisk makt til å starte et forløp der pasienter unngår unødig ventetid.

Regjeringen foreslår nå pakkeforløp også ved psykiske sykdommer. Målene er omfattende: Aktuelle pasienter skal raskere til avklaring og undersøkelser, behandlingen skal komme raskere i gang, det skal bli mer likeartet behandling på tvers av geografi og behandlingsenheter, pårørende skal involveres sterkere og det skal bli standarder for helsesjekk av psykisk syke. Dette helsepolitiske utspillet har satt i gang diskusjoner. Hvordan skal behandlingsresultater måles og dokumenteres? Hvilke negative bivirkninger kan standardiserte behandlingsopplegg ha for det individuelle møtet mellom terapeut og pasient? Mange innlegg er samlet av lege Henrik Vogt, som selv er kritisk til pakkeforløp $(1,2)$.

Danmark har siden 2012 hatt en landsomfattende ordning med pakkeforløp for ikke-psykotiske psykiske lidelser. Antall timer i pakken varierer med diagnosen. Det er for eksempel 15 timer i en angstpakke, $18 \mathrm{i}$ en depresjonspakke, $29 \mathrm{i}$ en pakke for posttraumatisk stresslidelse og $59 \mathrm{i}$ en pakke for emosjonell ustabil personlighetsforstyrrelse. Det er ikke noe krav om en bestemt terapiretning, så lenge det er kunnskapsgrunnlag for den valgte metoden. Henvisning til pakkeforløp sendes ett sentralt kontor i helseregionen, der spesialister tar stilling til videre behandling. Så skal dette igangsettes innen to måneder.

En dansk overlege i psykiatri skriver at pasientene stort sett er tilfredse med forløpet, men at det er eksempler på at ressursene flyttes fra de svakeste, som ikke passer inn i noen pakker (3). Andre peker på at tillit til profesjonell faglighet er blitt erstattet av kontroll, excelark og overvåking. De advarer mot at pakkene innføres som et rent økonomisk styringsredskap (4).

Som fastlege i Oslo har jeg positive erfaringer med noe som kan likne pakkeforløp, nemlig Poliklinikken Raskere tilbake ved Vinderen DPS. Tilbudet er rettet mot pasienter med angst og depresjon, som er sykmeldt eller står i fare for å bli sykmeldt. Henvisninger fra fastleger blir vurdert kontinuerlig, og pasienten innkalles raskt til en erfaren psykolog som vurderer om tilbudet er egnet. I ventetiden tilbys pasienten kurs i angst og depresjonsmestring. Den individuelle terapien består av inntil ti konsultasjoner. På vårt fastlegekontor har vi også månedlige møter med psykiater fra distriktspsykiatrisk senter der vi drøfter konkrete pasienter. Dette er meget nyttig.
Kreftsykdommer er mer håndfaste og avgrensede enn psykiske sykdommer. Ved mistanke om kreft skjer utredning og behandling i spesialisthelsetjenesten. Ved vanlige psykiske plager som depresjon, angst og søvnforstyrrelser skjer mye i primærhelsetjenesten. Veiledning og samarbeid mellom spesialist og fastlege ved møter eller felleskonsultasjoner burde skje i større grad, men inngår ikke naturlig i effektive pakkeforløp.

Hvem skal fastlegen henvise og hvem ikke? Ofte medvirker sorg, skuffelser og konflikter i privatliv og arbeidsliv til nedsatt funksjonsevne. Det kommer ikke frem i statistikken, siden såkalte Z-diagnoser ikke gir grunnlag for sykmelding. Vårt system innbyr allerede til medikalisering av vanlige livshendelser (5). Pakkeforløp kan forsterke dette.

Pakkeforløp kan bli oppfattet av pasientene som en rettighet til spesialistbehandling. Både allmennleger og pasienter vil lære hvordan en henvisning skal formes for å passe med kriteriene. Fastleger med mindre interesse for denne delen av allmennmedisinen kan lettere etterkomme pasientens bestilling ved å henvise til «noen å snakke med». Med pakkeforløp kan ressursene i spesialisthelsetjenesten bli vridd bort fra personer som ikke passer inn; rusbrukere, pasienter med alvorlige psykiske sykdommer og personlighetsforstyrrelser. Dette er mennesker som ikke trenger psykoterapi for å bli «friske», men som trenger støtte og hjelp i dårlige perioder, der samarbeid mellom primærhelsetjenesten og spesialisthelsetjenesten er viktig.

Det er bra at regjeringen ønsker å bedre helsevesenets tilbud til psykisk syke. Det er opp til oss som fagfolk å gi denne politiske viljen en fornuftig retning. Norske allmennleger, psykiatere og psykologer kan med fordel bedre kontakten med kollegene i Danmark. Våre helsemyndigheter kan bidra ved å gjøre danske evalueringer av pakkeforløpene lett tilgjengelig. I den nåværende fasen trenger vi åpen diskusjon, både om grunnleggende spørsmål, samarbeid og organisering.

Sverre Lundevall

slundevall@gmail.com

Sverre Lundevall (f. 1950) er spesialist i allmennmedisin, veileder i allmennmedisin og fastlege i Oslo. Han har i mange år arrangert innføringskurs i kognitiv atferdsterapi for allmennleger.

Forfatter har fylt ut ICMJE-skjemaet og oppgir ingen interessekonflikter

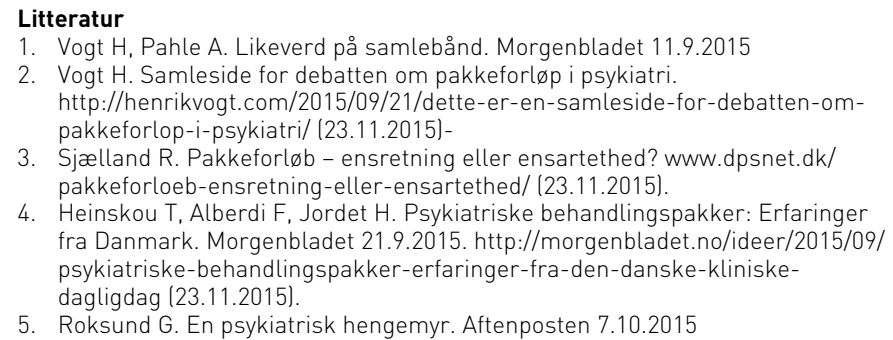

Litteratu pakkeforlop-i-psykiatri/ (23.11.2015)-

. Sjælland R. Pakkeforløb - ensretning eller ensartethed? www.dpsnet.dk pakkeforloeb-ensretning-eller-ensartethed/ (23.11.2015).

fra Danmark. Morgenblat 21.92015 . htt.//morgenbladet no/ideer/2015/09/ psykiatriske-behandlingspakker-erfaringer-fra-den-danske-kliniske-

5. Roksund G. En psykiatrisk hengemyr. Aftenposten 7.10.2015 